Chicago-Kent College of Law

Scholarly Commons @ IIT Chicago-Kent College of Law

All Faculty Scholarship

Faculty Scholarship

January 2009

\title{
Proving Facts: Belief versus Probability
}

Richard W. Wright

IIT Chicago-Kent College of Law, rwright@kentlaw.iit.edu

Follow this and additional works at: https://scholarship.kentlaw.iit.edu/fac_schol

Part of the Torts Commons

\section{Recommended Citation}

Richard W. Wright, Proving Facts: Belief versus Probability, 79 (2009).

Available at: https://scholarship.kentlaw.iit.edu/fac_schol/709

This Contribution to Book is brought to you for free and open access by the Faculty Scholarship at Scholarly Commons @ IIT Chicago-Kent College of Law. It has been accepted for inclusion in All Faculty Scholarship by an authorized administrator of Scholarly Commons @ IIT Chicago-Kent College of Law. For more information, please contact jwenger@kentlaw.iit.edu, ebarney@kentlaw.iit.edu. 


\title{
IV. Proving Facts: Belief versus Probability
}

\author{
Richard W. Wright
}

\section{A. Proving Facts in the Common Law and the Civil LaW: Radically Different Standards OF PERSUASION?}

\begin{abstract}
Although it comes as a great surprise to most American lawyers and legal scholars, it is commonly assumed by those familiar with civil (non-criminal) trial procedures in both common law and civil law jurisdictions that there is a radical difference between the standards of proof in the two types of jurisdictions. ${ }^{1}$ Yet, despite the assumed difference and the great practical as well as theoretical significance of the topic, not much is said about the burden of proof in monographs on comparative tort law, and what little is said tends to focus on the allocation of the burden rather than on its content. ${ }^{2}$
\end{abstract}

The general rule in both types of jurisdictions is that the plaintiff bears the burden of proving the prima facie case against the defendant (the defendant's tortious causation of the harm allegedly suffered by the plaintiff), while the defendant bears the burden of proving any affirmative defenses. ${ }^{3}$ However, the burden is sometimes shifted to the defendant on one or more elements of the prima facie case. This occurs much more often in civil law jurisdictions, through presumptions or explicit reversals of the burden of proof, than in common law jurisdictions. ${ }^{4}$

1 E.g., K.M. Clermont/E. Sherwin, A Comparative View of Standards of Proof, American Journal of Comparative Law (AJCL) 50 (2002) 243 ff.; C. Engel, Preponderance of the Evidence versus Intime Conviction: A Behavioral Perspective on a Conflict Between American and Continental European Law, Vermont Law Review (Vermont L Rev) 33 (2009) 435 ff.; J. Kokott, The Burden of Proof in Comparative and International Human Rights Law (1998) 18.

2 E.g., C. van Dam, European Tort Law (2006) 281 ff.; W. van Gerven/J. Lever/P. Larouche, Case, Materials and Text on National, Supranational and International Tort Law (2000) sec. 4.2.3 (available at http://www.casebooks.eu/tort/chapter4.php) accessed on 16 July 2009.

3 Clermont/Sherwin, AJCL 50 (2002) 248; M. Kazazi, Burden of Proof and Related Issues: A Study on Evidence Before International Tribunals (1995) $57 \mathrm{ff}$.

4 P.L. Murray/R. Stürner, German Civil Justice (2004) 267 ff.; van Dam (fn. 2) 281 ff.; van Gerven/Lever/Larouche (fn. 2) sec. 4.2.3; European Commission, European Judicial Network in Civil and Commercial Matters, Taking of evidence and mode of proof (available at http:// ec.europa.eu/civiljustice/evidence/evidence_gen_en.htm) accessed 30 June 2009; short form: EC EJN Evidence and Proof. 
Among the various possible explanations for this difference, two are based on real or assumed differences between the two types of jurisdictions with respect to the two aspects of the burden of proof.

3 The first aspect is the burden of producing evidence. It is generally much more difficult for plaintiffs in civil law jurisdictions to obtain relevant evidence, which often is in the hands of or more readily available to the defendant. The parties in civil law jurisdictions do not have the extensive (perhaps too extensive) "discovery" procedures available in common law jurisdictions - especially in the United States - to compel production of evidence, nor do judges in civil law jurisdictions generally have such power, except in France, where the power is seldom used. ${ }^{5}$

4 The second aspect is the burden of persuasion, including the standard of persuasion, which is the focus of this essay. In common law jurisdictions, there is a clear and explicit distinction between the standard of persuasion in criminal and civil proceedings. In criminal proceedings, the standard is very high: the prosecutor must prove the defendant's guilt "beyond a reasonable doubt". In civil proceedings, however, the plaintiff generally only needs to prove his case by the much lower standard of a "preponderance of the evidence" (the usual formulation in the United States) or a "balance of probability" (the usual formulation in the United Kingdom, the British Commonwealth and Scandinavia). Both the preponderance standard, which is often rephrased or interpreted as a "more likely than not" standard, and the "balance of probabilities" standard are commonly interpreted as merely requiring a $50+$ percent probability. ${ }^{6}$

5 In most civil law jurisdictions, on the other hand, there is a common, but not universal, assumption that the standard of persuasion is the same for civil and criminal proceedings. The plaintiff in a civil case, as well as the prosecutor in a criminal case, must provide sufficient proof to convince the trier of fact of the truth of the facts at issue on the particular occasion. This is phrased in France and elsewhere as a requirement that the trier of fact have an "intime conviction," an inner, personal, subjective conviction or belief in the truth of the facts at issue. It is often stated that the required conviction can only be established by proof beyond a reasonable doubt, or proof that "silences doubts without completely excluding them." Although it is recognized that absolute certainty is impossible to achieve, the required degree of belief is often expressed in terms of a virtual certainty, or at least a very high probability. However, a mere

5 Clermont/Sherwin, AJCL 50 (2002) 248, 265 f.; M. Taruffo, Rethinking the Standards of Proof, AJCL 51 (2003) 659 ff., 675.

${ }^{6}$ Clermont/Sherwin, AJCL 50 (2002) 243, 251 f. and fn. 39, 257, 261 fn. 86; Kokott (fn. 1) 18 f. Sometimes an intermediate standard is used, according to which the plaintiff must prove her case by "clear and convincing evidence." Clermont/Sherwin, AJCL 50 (2002) 251; Kokott (fn. 1) 19 $\mathrm{f}$. The interpretation of the preponderance of the evidence standard as a mere 50+ percent probability standard is literally implemented by Kokott, who refers to the preponderance standard as a "preponderance of probabilities." Kokott (fn. 1) 20. 
probability, no matter how high, will not suffice in the absence of the required conviction or belief in the truth of the facts at issue. ${ }^{7}$

Shifting the burden of proof to the defendant, explicitly or through rebuttable presumptions, compensates for the lack of discovery procedures and the assumed very high standard of persuasion in civil law jurisdictions. However, given the assumed very high standard of persuasion that is thereby placed on the defendant, the shift of the burden of proof overcompensates and, perhaps intentionally, effectively converts civil code provisions basing liability on fault into strict liability regimes.

Common law lawyers find it hard to understand why the very high standard of persuasion required for a criminal conviction should also apply in a civil liability action. ${ }^{8}$ Some of them also believe that the civil law's rejection of proof by statistical probabilities and its insistence that the trier of fact instead be convinced of the truth of the facts at issue is naïve, irrational, "strange" and "very odd," especially when such conviction is interpreted as requiring virtual certainty. They note that nothing is certain, that all evidence merely gives rise to probabilities regarding the facts at issue, and that the $50+$ percent probability standard best serves the assumed goal of minimizing errors. ${ }^{9}$ They also question the focus on conviction, belief, and truth in civil law jurisdictions given the very limited means for acquiring relevant evidence in those jurisdictions. ${ }^{10}$

Conversely, many civil law lawyers believe that it is naïve to believe that mere statistical probabilities can establish what actually happened in a particular case, and they find it hard to understand why a defendant should be held civilly liable based merely on such aggregate class-based probabilities, in the absence of evidence sufficient to convince the trier of fact of what actually happened in the particular case. Believing that the common law's "preponderance of the evidence" and "balance of probability" standards allow such proof, they reject both standards, at least as so interpreted. ${ }^{11}$

I argue in this essay that the supposed radical difference between the standard of persuasion in civil cases in common law and civil law jurisdictions is greatly overstated. In both types of jurisdiction, the plaintiff generally must provide evidence sufficient to convince the trier of fact of the truth of the facts at issue in the particular situation; a mere statistical probability, no matter how high, is insufficient. On the other hand, in both types of jurisdictions the required degree of conviction by the trier of fact is far below a virtual certainty.

7 Clermont/Sherwin, AJCL 50 (2002) 243 ff., 254 ff.; EC EJN Evidence and Proof (fn. 4); Kokott (fn. 1) 18 f.; F.H.S. Bridge, The Council of Europe French-English Legal Dictionary (2002) 173 (defining "intime conviction" as "reasonable conviction; reasonable certainty; state of being satisfied beyond reasonable doubt (personally convinced); personal conviction of the court (after considering all the evidence)").

8 E.g. Clermont/Sherwin, AJCL 50 (2002) 243 ff.; Engel, Vermont L Rev (2009) 345 ff.

9 E.g. Clermont/Sherwin, AJCL 50 (2002) 243 f., 251 f., 258 f., 267, 271, 273 f.

10 Id. $249 \mathrm{f}$.

11 E.g. Taruffo, AJCL 51 (2003) 659, 663 f., 667 ff. 
10 The seeming conflict between the civil law's focus on conviction or belief and the common law's focus on likelihood or probability is based on a failure of those on each side of the conflict to appreciate that, while it is true that all proof involves probabilities, there are different types of probabilities, only one of which - which is not statistical in nature - is sufficient to justify a belief about what actually happened on a particular occasion. The failure to appreciate this fact has prevented academics and courts in both types of jurisdictions from clearly perceiving the relevant issues and has led to troublesome doctrines with paradoxical implications in an increasing number of situations.

11 In Parts B and C of this essay, I discuss, respectively, the standards of persuasion in civil law jurisdictions and the standards of persuasion in common law jurisdictions. In Part D I discuss the various types of probabilities and their relevance in proving the facts at issue in a particular case. In Part E I discuss some doctrinal problems and paradoxes that are created by the statistical probability interpretation of the standard of persuasion.

\section{B. The Standards of Persuasion in the Civil LAW}

12 Michele Taruffo argues persuasively that the common conception of the standard of persuasion in civil law jurisdictions is incorrect. ${ }^{12}$ As he states, "no rule, in any civil law system, requires the courts to apply in civil cases the same standard of proof that is applied in criminal cases." ${ }^{\text {13 }}$

13 One might argue for such an equation based on the similarity of the relevant provisions in the German codes of criminal and civil procedure. Sec. 261 of the Code of Criminal Procedure states:

The court shall decide on the result of the evidence taken according to its free conviction gained from the hearing as a whole. ${ }^{14}$

14 Subsec. 1 of sec. 286 of the Code of Civil Procedure states:

The court shall decide at its free discretion, by taking into account the whole substance of the proceedings and the results of any evidence taking, whether a factual allegation should be regarded as true or untrue. The grounds which prompted the court's conviction shall be stated in the judgment. ${ }^{15}$

${ }^{12}$ Id. $659 \mathrm{ff}$.

${ }^{13}$ Id. 665.

${ }^{14}$ C.J.M. Safferling, Terror and Law - Is the German Legal System able to deal with Terrorism? - The Bundesgerichtshof (Federal Court of Justice) decision in the case against El Motassadeq, German Law Journal 5 (2004) 515, 520.

${ }^{15}$ S.L. Goren, The Code of Civil Procedure Rules of the Federal Republic of Germany of January 30, 1877 and the Introductory Act for the Code of Civil Procedure Rules of January 30, 1877 (1990) at 73. 
However, while both provisions state the need for the judge to be convinced regarding the truth of the fact(s) at issue, neither provides any standard for reaching that conviction or requires that whatever standard is employed be the same in criminal and civil proceedings. To the contrary, each emphasizes the judge's discretion in reaching that conviction based on his or her "free evaluation" of all the available evidence, unconstrained by rigid rules of legal proof, such as the hearsay rules in the common law and the weighting of different types of evidence and mathematical calculation of "full proof" that existed under the French regime of "preuve légale" prior to the adoption of the civil codes. ${ }^{16}$

The same point holds for the "intime conviction" standard that is commonly said to apply in French criminal and civil proceedings. There is no mention of this standard (or any other standard) in the French Civil Code or the Code of Civil Procedure. ${ }^{17}$ It is mentioned in the French Code of Criminal Procedure. Art. 304 requires each juror of the Assize Court to swear "to remember that the accused is presumed innocent and that he has the benefit of the doubt; to decide according to the charges and defence arguments following your conscience and your innermost conviction,"18 and art. 353 requires the following instruction to be read to the jury and "put up in large type in the most visible part of the deliberation chamber" before the jury retires for deliberation:

The law does not ask the judges [jurors] to account for the means by which they convinced themselves; it does not charge them with any rule from which they shall specifically derive the fullness and adequacy of evidence. It requires them to question themselves in silence and reflection and to seek in the sincerity of their conscience what impression has been made on their reason by the evidence brought against the accused and the arguments of his defence. The law asks them but this single question, which encloses the full scope of their duties: are you inwardly convinced? ${ }^{19}$

Although phrased in a more explicit subjective manner (but consider the reference to the judge's "free discretion" in sec. 286 of the German Code of Civil Procedure), the "intime conviction" standard had the same genesis and aim as the relevant provisions in the German codes: a replacement of the prior rigid rules of legal proof with the "free evaluation" of all the relevant evidence by the judge, who is to decide cases according to her own inner, personal, subjective, "intimate" conviction. ${ }^{20}$ As Taruffo states,

16 Taruffo, AJCL 51 (2003) 666 f.; see Clermont/Sherwin, AJCL 50 (2002) 244 f. The judge's "free evaluation" is not completely unconstrained. In addition to the substantial limitations on the power of the parties or the judge to obtaining access to relevant evidence, some legal proof rules continue to exist, especially in France. See Clermont/Sherwin AJCL 50 (2002) 249; $R$. Vouin, The Exclusionary Rule: France, Journal of Criminal Law, Criminology, and Police Science (JCLCPS) 52 (1961) 275 ff. But cf. Taruffo, AJCL 51 (2003) 661, 674 f.

17 Clermont/Sherwin, AJCL 50 (2002) 254; Taruffo, AJCL 51 (2003) 667.

${ }^{18}$ Code of Criminal Procedure art. 304 (available in English at http://Legifrance.gouv.fr/) accessed on 15 July 2009.

19 Id. art. 353.

${ }^{20}$ M. Foucault, Abnormal: Lectures at the Collège de France 1974-1975, at 6-8 (F. Ewald \& A. Fontana eds., G. Burchell transl. 2003); Taruffo, AJCL 51 (2003) 666 f. 
The principle of the intime conviction and all the similar (but not identical) principles concerning the free evaluation of proofs do not by themselves entail the adoption of any specific standard of proof, let alone the standard of proof beyond reasonable doubt. The history of these principles, as well as their systematic role in modern systems, show that they have a negative rather than a positive meaning. Their negative meaning is that to the extent they are applied (which is in many cases a matter of degree) they exclude the application of rules of legal proof (i.e., rules determining in general and binding terms the probative force of specific items of evidence), vesting the court with the power to determine the weight of proofs on the basis of a discretionary evaluation. In a word: these principles exclude the application of legal standards of proof but do not prescribe by themselves any positive standard of proof. ${ }^{21}$

18 I would amend Taruffo's statement in one significant respect. I believe the references to the judge's "conviction" in the French "intime conviction" standard and the German criminal and civil code provisions quoted above do provide a minimum standard of persuasion: the judge is required to have a conviction or belief regarding the truth of the fact at issue. This is the core of the civil law approach to proof, which is thought to be absent in the common law's preponderance and balance of probability standards. Taruffo himself subsequently emphasizes that "not only is truth the main goal stated by the already mentioned $\S 286$ of the Zivilprozessordnung, the search for truth is the main reference point of the German legal theory concerning the problems of proof ...."22

19 However, I agree with the basic point that Taruffo makes: the "intime conviction" standard by itself does not specify what degree of conviction is required. Its conjunction with the presumption of innocence and, more specifically, the benefit of the doubt that a juror in the Assize Court is required to grant to the defendant in art. 304 of the French Code of Criminal Procedure provides support to those who restate the criminal standard as a "deep-seated" or "profound" conviction, ${ }^{23}$ perhaps comparable to the "beyond a reasonable doubt" standard but perhaps only requiring something like the "clear and convincing evidence" standard. However, there is no support in the French codes for requiring any particular degree of "inner conviction" in civil actions.

20 Kevin Clermont and Emily Sherwin argue that the strong preference that civil plaintiffs have in France for joining their civil action to a related criminal action (as allowed in France and some other civil law jurisdictions) proves that the standard of persuasion in the civil action is at least as high as (the assumed) very high standard in the criminal action; otherwise civil plaintiffs would prefer to pursue their action in the civil courts rather than the criminal courts even though they, rather than the public prosecutor, would bear the costs of litigation. ${ }^{24}$

${ }^{21}$ Taruffo, AJCL 51 (2003) 666.

22 Id. 675.

${ }^{23}$ E.g, Foucault (fn. 20) 7 ff. ("profound"); Vouin, JCLCPS 52 (1961) 275 ff. ("deep-seated").

${ }^{24}$ Clermont/Sherwin, AJCL 50 (2002) 264. 
There are a number of problems with this argument. First, even if the standards were the same, the standard could be low rather than high. Taruffo makes this point with particular reference to the situation in Italy, where plaintiffs also have a strong preference for joining their civil action with the related criminal action. He notes that a recent overview of the Italian case law "shows that Italian courts in deciding civil cases adopt very flexible standards of proof, based essentially upon the discretion of the judge, without any reference to the standard of proof beyond reasonable doubt," ${ }^{25}$ and that the late Federico Stella, a leading Italian scholar and prominent practitioner of criminal law, strongly criticized the Italian courts for applying in criminal actions "the much lower standard, that is typical of civil cases, of the prevailing probability" rather than the "beyond a reasonable doubt" standard. ${ }^{26}$ Stella's criticism actually was even stronger: he faulted the Italian courts for applying a stricter standard of persuasion in civil cases than in criminal cases, and he forcefully argued for the adoption of the "beyond a reasonable doubt" standard in criminal actions and the "preponderance of the evidence" standard in civil actions in place of the amorphous and manipulable "inner persuasion" standard. ${ }^{27}$

Second, Clermont and Sherwin's argument ignores the very high costs of litigating in the civil courts, especially given the "loser pays" rule under which the loser of the civil case has to pay the litigation costs of the other party, which often would make pursuing one's civil action in the criminal proceeding the only financially feasible option, or at least so much cheaper as to outweigh the advantage of a lower standard of persuasion in the civil court.

Third, Clermont and Sherwin's argument assumes the point supposedly being proven, that the criminal courts apply the same standard of persuasion in the joined civil action as in the criminal action.

If the civil standard of persuasion were (at least) as high as the criminal standard of persuasion, the acquittal of the defendant in a criminal action should have conclusive effect in any non-final civil action involving the same facts. The fact that this at one time was the case in France, despite the absence of any code provision mandating that result, has been put forth by Clermont and Sherwin as evidence of the identity of the criminal and civil standards in civil law jurisdictions, even though they state that the same rule does not apply in most of France's neighboring countries. ${ }^{28}$ However, recent changes to the

25 Taruffo, AJCL 51 (2003) 665 fn. 26, citing F. Carpi/M. Taruffo (eds.), Commentario breve al codice di procedura civile. Complemento giurisprudenziale (3rd ed. 2002) 477. Examples of the widely varying standards that have been employed by the Italian courts with respect to the causation issue in medical malpractice cases are provided in a forthcoming paper by Claudia DiMarzo: Trib. Florence 2222 [1999] ("reasonable certainty"); Cass. Civ. 11522 [1997] ("concrete, actual and not hypothetical possibility of a favorable outcome"); Cass. Civ. 4725 [1993] ("reasonable certainty about the existence of a not insignificant probability"); Cass. Civ. 4044 [1994] ("moral certainty"); Cass. Civ. 1286 [1998] ("reliable and significant possibility of a favorable outcome").

26 Taruffo, AJCL 51 (2003) 665, citing F. Stella, Giustizia e modernità (2nd ed. 2002) 147, 328.

27 Stella (fn. 26); F. Stella, Causation in Products Liability and Exposure to Toxic Substances: A European View, in: M.S. Madden (ed.), Exploring Tort Law (2005) 403 ff.

${ }^{28}$ Clermont/Sherwin, AJCL 50 (2002) 263 f. 
French Code of Criminal Procedure, beginning in 1983, explicitly state that the civil action can proceed, in the criminal court or the civil court as appropriate, despite the acquittal of the defendant in the criminal action. ${ }^{29}$ This makes little sense unless, as in common law jurisdictions, the civil standard is lower than the criminal standard.

25 Speculation about the identity or divergence of the criminal and civil standards of persuasion is no longer necessary with respect to the situation in Italy. The Italian Supreme Court of Cassation has explicitly adopted the "beyond a reasonable doubt" standard for criminal actions and the "preponderance of the evidence" standard for civil actions, while emphasizing that satisfaction of the preponderance standard requires evidence specific to the particular case rather than a mere statistical probability:

As this Court has previously stated, the main difference [between the penal and civil processes] is in the standards of proof that each system requires (Cass. Pen., S.U., 11.09.2002, n. 30328).

The Penal Code requires proof "beyond a reasonable doubt" while the Civil Code merely requires a "preponderance of the evidence." The different standards correspond to the different values at stake in each system (Cass. 16.10.2007, n. 21619; Cass. 18.04.2007, n. 9238; Cass. 05.09.2006, n. 19047; Cass. 04.03.2004, n. 4400; Cass. 21.01.2000, n. 632).

The Court of Justice CE has recently stated that causation cannot be based on probabilities (CGCE 13.07.2006, n. 295; CGCE 15.02.2005, n. 12).

The concept of "probabilistic certainty" is a standard that is necessary in all civil cases. The mere statistical likelihood that one act or omission caused certain harm is not enough to impose liability. Probabilistic certainty also requires evidence from the specific case to support that statistical likelihood. ${ }^{30}$

26 In civil law jurisdictions other than Italy, there is little empirical information regarding the standards of persuasion actually applied by the courts, and sometimes very little guidance in judicial opinions, especially in France, where appellate judges do not review facts and write extremely short, conclusive opinions with minimal if any elaboration of standards or rationales. ${ }^{31}$ However, anecdotal evidence indicates that, as in Italy, ${ }^{32}$ the standard of persuasion in France, even in criminal proceedings, ${ }^{33}$ varies depending on the discretion of the judge. This is also said to be the case in Germany. ${ }^{34}$ Even Clermont and Sherwin conclude that

${ }^{29}$ E.g., Code of Criminal Procedure art. 4-1, 371 f., 470-1.

${ }^{30}$ Cass. Civ. Sez. Un. 581 [2008] § 3.9 (translated by Claudia DiMarzo, University of Palermo). The concept of "probabilistic certainty" is discussed in Part D below.

${ }^{31}$ See Clermont/Sherwin, AJCL 50 (2002) 254, 257.

${ }^{32}$ See supra no. 21.

${ }^{33}$ E.g., Foucault (fn. 20) 8-11.

${ }^{34}$ Murray/Stürner (fn. 4) 310 ff.; P. Gottwald, "Fact Finding: A German Perspective," in: D.L.C. Miller/P. R. Beaumont (eds.), The Option of Litigating in Europe (1993) 67, 77 (stating that German courts apply a preponderance standard "with regard to prima facie cases, to causation, to negligence and to assessment of damages"). 
the supposed identity of the (very high) criminal and civil standards of persuasion in civil law jurisdictions is a myth, which they argue is purposely maintained by the courts to shore up their legitimacy. ${ }^{35}$ They state that "civil-law judges likely apply a haphazardly variable civil standard of proof," 36 and they cite scholars who believe that the civil standard is closer to the preponderance standard than the "beyond a reasonable doubt" standard. ${ }^{37}$ However, contrary to Clermont and Sherwin's identification of the civil standard of persuasion with mere statistical probability, ${ }^{38}$ civil-law judges and lawyers generally seem to agree with the Italian court's rejection of that identification and its insistence that evidence specific to the particular case is necessary in order to form the required conviction regarding what actually happened in that case. ${ }^{39}$

\section{The Standards of Persuasion in the COMMON LAW}

As I have previously noted, many academics in both common law and civil law jurisdictions assume that the "preponderance of the evidence" standard of persuasion, at least as employed in the United States, merely requires a $50+$ percent statistical probability. The same assumption applies, through literal interpretation, to the "balance of probability" standard that is employed in common-law jurisdictions outside the United States. For both standards, as so interpreted, it would be better to employ the term "standard of proof" rather than "standard of persuasion," since the latter implies an element of conviction or belief that is lacking when all that is involved is a class-based statistical probability. Happily, however, the term "standard of persuasion" can be retained without awkwardness or misdescription, since the statistical probability interpretation of these standards, as they are usually understood and applied, is incorrect. The evidence that I provide in support of this statement is limited to the preponderance standard, due to limitations of space and personal knowledge. However, I believe that similar evidence could easily be adduced for the "balance of probability" standard by someone knowledgeable about the practice in a jurisdiction that employs that standard. Additional arguments applicable to both standards are provided in Part E below.

Contrary to the common assumption among academics, the preponderance standard in the United States has traditionally been understood by judges and presented to juries as a standard of conviction or belief regarding the truth of the fact(s) at issue rather than as a matter of mere mathematical or statistical probability. A widely employed pattern jury instruction states:

${ }^{35}$ Clermont/Sherwin, AJCL 50 (2002) 258 f., 269 ff.

${ }^{36}$ Id. 273.

37 Id. 261, citing, among other sources, ALI/UNIDROIT Principles and Rules of Transnational Civil Procedure P-18A, R-31E (Discussion Draft No. 3, 2002). See also Murray/Stürner (fn. 4) $310 \mathrm{ff}$.

38 Clermont/Sherwin, AJCL 50 (2002) 265.

39 Taruffo, AJCL 51 (2003) 659, 663 f., 667-71; EC EJN Evidence and Proof (fn. 4). 
To "establish by a preponderance of the evidence" means to prove that something is more likely so than not so. In other words, a preponderance of the evidence in the case means such evidence as, when considered and compared with that opposed to it, has more convincing force, and produces in your minds belief that what is sought to be proved is more likely true than not true. This rule does not, of course, require proof to an absolute certainty, since proof to an absolute certainty is seldom possible in any case. ${ }^{40}$

29 The core of this instruction is essentially identical to the standards of persuasion enunciated in the German codes of criminal and civil procedure. While the American instruction does not include the "free evaluation of the evidence" principle that is stressed in the German provisions, it has the same focus on the required formation of a conviction or belief in the truth of the facts at issue. In addition, unlike the German provisions, it specifies the required degree of that belief. The required degree of belief is by a bare preponderance of the evidence, barely sufficient for the formation of a belief in the truth of the facts at issue: the slightest degree of belief, ${ }^{41}$ rather than the much stronger degrees of belief required under the "clear and convincing evidence" or "beyond a reasonable doubt" standards, which are more literally worded belief (rather than mere probability) standards.

30 As in the quoted instruction, jury instructions in the Unites States generally refer to proof that the disputed fact is "more probably true than not true," rather than simply "more likely than not" as a matter of abstract class-based statistics. ${ }^{42}$ When "more likely than not" or some similar phrase is employed, it is usually clear from the surrounding language that the phrase is not being used to refer to a mere $50+$ percent statistical probability, but rather to refer to the truth of what actually happened on the particular occasion.

31 Few American judges, jurors, or laypersons interpret the "preponderance of the evidence" standard or even the "more probable than not" standard as merely requiring a $50+$ percent statistical probability. In the well-known Cipillone case, the U.S. Court of Appeals for the Third Circuit questioned attempts by some courts and commentators to use mere statistics to define and prove "but for" causation:

${ }^{40}$ E.H. Devitt et al., Federal Jury Practice and Instructions (Civil) (4th ed. 1987) vol. $3 \S 72.01$, at 32 (emphasis added); see R.W. Wright, Causation, Responsibility, Risk, Probability, Naked Statistics, and Proof: Pruning the Bramble Bush by Clarifying the Concepts, Iowa Law Review (Iowa L Rev) 73 (1988) 1001, 1065 and fns. 337-339 (citing numerous sources).

41 See Livanovitch v. Livanovitch, 131 A. 799, 800 (Vt. 1926) ("If ... you are more inclined to believe from the evidence that he did so deliver the bonds to the defendant, even though your belief is only the slightest degree greater than that he did not, your verdict should be for the plaintiff." (quoting the trial court's jury instructions)).

42 E.g., Illinois Supreme Court Committee on Pattern Jury Instructions in Civil Cases, Illinois Pattern Jury Instructions: Civil (2006) § 21.01 ("more probably true than not true"); short form: Illinois Pattern Jury Instructions; L. Sand et al., Modern Federal Jury Instructions (2007) vol. 4, $\S 73.01$, Instruction 73-2 (stating that "by a preponderance of the evidence" means "more likely true than not true," considering the "weight" and "quality and persuasiveness" of the evidence). 
We are not convinced that when a jury determines that "but for" a defendant's conduct, the injury would not have occurred, it is determining that the chances of that injury being the result of defendant's conduct are $50 \%$ or greater. Traditionally, jury instructions have been in words, not numbers. ${ }^{43}$

When asked to do so by researchers, many judges similarly object to interpreting standards of persuasion in terms of quantitative probabilities. ${ }^{44}$ In one survey, 80 out of 255 judges refused to specify a probability sufficient for a "preponderance of the evidence" finding. ${ }^{45}$ Of the judges who were willing to do so, only about three-fifths chose a probability of 50 to 55 percent; about two-fifths chose a probability of 60 percent or greater, almost one-fifth a probability of 70 percent or greater, one-tenth a probability of 80 percent or greater, and one-twentieth a probability of 90 to 100 percent. ${ }^{46}$ The distribution of probabilities was about the same for the "more probable than not" standard. ${ }^{47}$ Laypersons - jurors and students - were even less willing to interpret the preponderance standard as a mere $50+$ percent probability. About four-fifths of the laypersons chose a probability of 70 percent or greater, half a probability of 80 percent or greater, and more than one-tenth a probability of 95 to 100 percent. ${ }^{48}$ Over 90 percent of the judges and about two-thirds of the laypersons were opposed to having jurors simply make a probability finding, which the judge would then use to determine liability. ${ }^{49}$ Trial consultants advise American plaintiffs" lawyers that "[m] any jurors will not agree to decide on the basis of 80 percent or 70 percent or 60 percent certainty," but rather "expect you to prove your case beyond a reasonable doubt, and you won't change their minds by explaining preponderance." Instead, the trial consultants advise, repeatedly get witnesses to testify that something is "more likely right than wrong" and, "beyond that," that they are "certain" of the truth of the fact at issue. ${ }^{50}$

American courts also usually agree with the civil law jurisdictions that, to prove what actually happened in a particular case - to establish what the facts actually were in that case - the party with the burden of persuasion regarding

43 Cipollone v. Liggett Group, Inc., 893 Federal Reporter, Second Series (F.2d) 541, 561 fn. 17 (3rd Cir. 1990).

44 C.M.A. McCauliff, Burdens of Proof: Degrees of Belief, Quanta of Evidence, or Constitutional Guarantees?, Vanderbilt Law Review (Vand L Rev) 35 (1982) 1293, 1332; R.J. Simon/L. Mahan, Quantifying Burdens of Proof: A View from the Bench, the Jury, and the Classroom, Law and Society Review (L Soc Rev) 5 (1971) 319, 329 (quoting judges as stating that "[p]ercentages or probabilities simply cannot encompass all the factors, tangible and intangible, in determining guilt - evidence cannot be evaluated in such terms").

45 McCauliff, Vand L Rev 35 (1982) 1325 fn. 184, 1330.

46 Id. 1331; Simon/Mahan, L Soc Rev 5 (1971) 324 f., 327 table 7.

47 McCauliff, Vand L Rev 35 (1982) 1331.

48 Simon/Mahan, L Soc Rev 5 (1971) 327 table 7; see also D.K. Kagehiro/W.C. Stanton, Legal vs. Quantified Definitions of Standards of Proof, Law and Human Behavior 9 (1985) 159, 164, 169 (discussing an empirical study demonstrating a divergence between subjects' findings under the preponderance standard and a quantified 51 percent standard, with results closer to those obtained under the preponderance standard even when the two standards were combined in the same instruction).

49 Simon/Mahan, L Soc Rev 5 (1971) 329, 330 fn. 8.

${ }^{50}$ D. Ball, Making Preponderance Work, Trial (Mar. 2008) 38 ff. 
those facts must employ evidence specific to that particular case, rather than mere statistical probabilities. In an often quoted statement, the Supreme Court of Massachusetts stated:

It has been held not enough that mathematically the chances somewhat favor a proposition to be proved; for example, the fact that colored automobiles made in the current year outnumber black ones would not warrant a finding that an undescribed automobile of the current year is colored and not black, nor would the fact that only a minority of men die of cancer warrant a finding that a particular man did not die of cancer. The weight or ponderance of evidence is its power to convince the tribunal which has the determination of the fact, of the actual truth of the proposition to be proved. After the evidence has been weighed, that proposition is proved by a preponderance of the evidence if it is made to appear more likely or probable in the sense that actual belief in its truth, derived from the evidence, exists in the mind or minds of the tribunal notwithstanding any doubts that may still linger there. ${ }^{51}$

34 Jury instructions often refer to the "weight" of the evidence. ${ }^{52}$ Abstract classbased statistics do not have weight. Only concrete "particularistic" evidence specific to the particular case has weight.

35 In sum, contrary to a widespread perception, there is strong agreement between civil law and common law jurisdictions regarding the standards of persuasion. True persuasion requires the formation of a conviction or belief regarding the truth of the facts at issue, and such belief cannot rationally be based on mere class-based statistics, but rather must be based on evidence specific to the particular instance. Furthermore, the required degree of belief varies in criminal actions and civil actions, given the different interests at stake in each action. For criminal actions, a very high degree of belief is required: no reasonable doubt can remain. For most issues in civil actions, however, the standard of persuasion is much lower: all that is required is the formation of a bare, minimal personal belief ("intime conviction") by the trier of fact in the truth of the facts at issue, as required by the usual understanding in practice (rather than in academia) of the preponderance of the evidence standard.

36 However, a critical objection or question remains. How is such a conviction or belief formed? Nothing is certain. All evidence, including particularistic evidence specific to the particular occasion - for example, fingerprint evidence and (especially) eyewitness testimony - merely gives rise to a probability regarding the facts at issue. ${ }^{53}$ Does it then make any sense to distinguish between

${ }^{51}$ Sargent v. Mass. Accident Co., 29 North Eastern Reporter, Second Series (N.E.2d) 825, 827 (Mass. 1940) (citations omitted).

${ }^{52}$ E.g., Sand (fn. 42) § 73.01, Instruction 73-2 (stating that "by a preponderance of the evidence" means "more likely true than not true," considering the "weight" and "quality and persuasiveness" of the evidence).

${ }^{53}$ The difficulties of attributing a specific piece of evidence to a particular source are examined in National Research Council, Strengthening Forensic Science in the United States: A Path Forward (2009). 
probability and belief? Even Taruffo apparently does not think that it does. Although he is critical of statistical probability interpretations of the standards of persuasion, he is also critical of standards that take seriously the concepts of conviction, belief, or truth. ${ }^{54}$

\section{Probabilities and Belief ${ }^{55}$}

The proponents of the $50+$ percent statistical probability interpretation rely on the truth that all evidence, including the particularistic evidence that is generally insisted upon by courts in both civil law and common law jurisdictions, is ultimately probabilistic. However, they fail to recognize that there are different types of probabilities, and that these different types of probabilities have differing relevance depending on the type of inquiry at issue.

In litigation and ordinary life, we are usually interested in determining what has actually happened in the past or predicting what is likely to or may happen in the future. Both types of inquiry rely on causal generalizations, which are incompletely specified causal laws. A causal law is a law of nature; it describes an invariable, nonprobabilistic connection between some fully specified set of antecedent conditions and some consequent condition, such that whenever all the listed antecedent conditions are instantiated on a particular occasion, that complete instantiation necessarily will produce the instantiation of the consequent condition. ${ }^{56}$ The antecedent conditions and the consequent condition are described as abstract types, which cannot in themselves cause anything. An actual singular instance of causation consists of the complete instantiation of a causal law on a particular occasion.

Our knowledge of the content of causal laws is based on experience and empirical investigation. The existence of such a law is usually inferred from observation of a constant or frequent conjunction between occurrences of some set of antecedent conditions and the subsequent (or simultaneous) occurrence of some other condition. However, the mere existence of a frequent, or even a constant, conjunction is not sufficient to establish a causal relation. ${ }^{57}$ Scientists engage in carefully designed experiments to determine whether there is an actual causal relation or, instead, the correlation is spurious, and, if there does seem to be a causal relation, to determine the direction of causation and, to the extent possible, all of the antecedent conditions in the causal law.

54 Taruffo, AJCL 51 (2003) 669-71.

55 Some of the text in this Part and the prior Part is excerpted from Wright, Iowa L Rev 73 (1988) and $R$. Wright, Liability for Possible Wrongs: Causation, Statistical Probability, and the Burden of Proof, Loyola of Los Angeles Law Review (Loy LA L Rev) 41 (2008) 1295.

${ }^{56}$ I have made no attempt to avoid circular use of causal terminology, since the exposition here is not intended to be an analysis of the meaning of causation but rather an explanation of the relationships among causation, probability and belief.

57 A.B. Hill, The Environment and Disease: Association or Causation?, Proceedings of the Royal Society of Medicine 58 (1965) 295; A. Scales, Legal Feminism: Activism, Lawyering, and Legal Theory (2006) $171 \mathrm{f}$. 
40 Our knowledge of causal laws is almost always incomplete, and even when it is complete we rarely refer to completely specified causal laws. We rather employ causal generalizations, which are incompletely specified causal laws that have only as much specificity as is possible and needed to resolve the causal issue in the particular situation. Since the causal generalization is not a complete specification of the causal law, instantiation of all of the antecedent conditions in the causal generalization does not guarantee the instantiation of the consequent condition. Instead, there is only a probability that the consequent condition will be instantiated. This probability is what I have called an ex ante causal probability. It is an aggregate, class-based probability associated with a particular causal generalization that describes the frequency of instantiation of the consequent condition given the complete instantiation of the antecedent conditions.

41 Ex ante causal probabilities are useful, indeed necessary, for causal prediction - predicting what is likely to or may happen in the future. However, they have only limited, redundant utility in causal explanation - explaining what actually happened on a particular occasion. As noted above, significant statistical correlations, such as are provided by epidemiological evidence, can be used - and often are used - to infer a general causal relation, what is often referred to in the law as "causal capacity" or "general causation." By themselves they are never sufficient (or necessary) for inferring a causal relation. However, if the causal relation is confirmed, the statistical frequency becomes an ex ante causal probability, which can be used for causal prediction.

42 Reference to an ex ante causal probability does not assist in establishing what is often referred to as "specific causation": the actual instantiation of the relevant causal generalization and its underlying causal law on a particular occasion. Reference to the statistical frequency that has been confirmed as an ex ante causal probability merely redundantly confirms and quantifies the "causal capacity" of the conditions in the antecedent of the causal generalization when they are instantiated. It does not provide any information about the actual instantiation of those conditions on a particular occasion.

43 An abstract ex ante causal probability associated with some possibly applicable causal generalization is not evidence of what actually happened on any particular occasion because it provides no information on whether the abstract elements in the causal generalization and the underlying causal law actually were instantiated on that occasion. It merely states that X percent of the time that the known abstract elements in the causal generalization are instantiated, the unknown abstract elements required to complete the causal law are also instantiated. It does not help us determine whether this particular occasion is one of the $\mathrm{X}$ percent in which the causal law was fully instantiated, or instead is one of the $100-\mathrm{X}$ percent in which the causal law was not fully instantiated. It can be used to place a bet on what most likely happened, but it cannot be used to resolve the bet. If a horse wins 90 percent of its races or the odds are 90 percent that a spin of a roulette wheel will not result in the ball's landing on a certain number, no one who placed a bet either way 
in either situation will consider themselves to have won or lost the bet in the absence of specific evidence of the actual outcome of the particular race or spin of the wheel.

A judgment on what actually happened on a particular occasion is a judgment on which causal generalization and its underlying causal law was fully instantiated on the particular occasion. An item of particularistic evidence is a concrete feature of a particular occasion that instantiates, or negates the instantiation of, one of the abstract elements in a possibly applicable causal generalization. Particularistic evidence connects a possibly applicable causal generalization to the particular occasion by instantiating the abstract elements in the causal generalization, thereby converting the abstract generalization into an instantiated generalization. Without such particularistic evidence, there is no basis for applying the causal generalization to the particular occasion.

To determine whether a specific causal law was fully instantiated, we use particularistic evidence to assess, non-quantitatively, the ex post probability that each of the abstract elements in the relevant causal law was instantiated - what I have called an ex post causal probability. This ex post causal probability of complete instantiation is distinct and independent from the ex ante causal probability associated with the relevant causal generalization. The ex post probability for complete instantiation of the causal law is equal to the lowest ex post probability for instantiation of any constituent element. The ex post probability for instantiation of the known abstract elements listed in the causal generalization is either based on direct particularistic evidence of such instantiation or, as with the unknown abstract elements required to complete the causal law, is circumstantially inferred from particularistic evidence of the network of causal relationships that encompasses the particular occasion. The final judgment on what actually happened depends on whether, in the mind of the trier of fact, the unquantified ex post probability associated with a possibly applicable causal generalization - the ex post probability, based on all the particularistic evidence, that the causal law underlying the causal generalization was fully instantiated - is sufficient, in comparison with the unquantified ex post probability associated with competing causal generalizations, to produce in the trier of fact the required degree of belief in the truth of the fact that the first causal generalization and its underlying law were the ones that were fully instantiated on the particular occasion.

A "naked statistic" is an accidental (non-causally related) distribution or frequency of occurrence - for example, the fact that most of the taxis in a town are operated by a particular company or that most of the bolts used by a particular manufacturer were supplied by a particular supplier. If the "preponderance of the evidence" and "balance of probability" standards of persuasion merely require proof of a 50+ percent statistical probability, a 50+ percent "naked statistic" should suffice to prove the fact at issue. Yet, when such naked statistics are presented to courts, in the United States or elsewhere, as alleged proof of the fact that it was the defendant's instrumentality (e.g., taxi or defective bolt) 
that tortiously caused the plaintiff's injury, they are almost always properly rejected as being irrelevant. ${ }^{58}$

47 Ex ante causal probabilities are relevant and necessary for causal prediction; they are irrelevant for causal explanation. Conversely, ex post causal probabilities are relevant and necessary for causal explanation; they are irrelevant for causal prediction. Naked statistics are irrelevant for both causal explanation and causal prediction, although they can be used to place a bet on the fact at issue.

48 The distinction between causal prediction and causal explanation underlies and supports the different standards of persuasion in sec. 286 and 287 of the German Code of Civil Procedure. Sec. 287, which deals with the determination of the damages resulting from a legal wrong, does not have sec. 286's reference to the necessary "conviction" of the trier of fact:

If it is controversial between the parties whether any damage was caused or the extent of the damage or of a compensable interest, it shall be decided by the court at its free discretion by taking into consideration all the circumstances. ${ }^{59}$

49 As the drafters of sec. 287 must have understood, no belief can be formed, but rather only predictions can be made, about the amount of future damages. Thus, sec. 287 omits the requirement that the trier of fact form a belief regarding such damages. The actual occurrence of the legal wrong is an issue of past fact or causal explanation, which is governed by sec. 286 , which properly requires the trier of fact to be convinced of the actual occurrence of the legal wrong. The determination of past damages is also an issue of past fact for which ex ante causal probabilities are irrelevant. However, on this issue most jurisdictions are willing, as the drafters of sec. 287 were,${ }^{60}$ to let the plaintiff recover damages even if there is insufficient proof for the trier of fact to form a belief regarding the precise amount, as long as there is sufficient evidence to support a reasonable estimation.

50 The failure to perceive the distinctions among the different types of probabilities and their disparate relevance to the different types of inquiries that arise in litigation exists in both common law and civil law jurisdictions. However, contrary to Clermont and Sherwin's claim that the judges, lawyers and academics in civil law jurisdictions are far behind those in the common law jurisdictions (especially the United States) in their understanding of the relationship between probability and proof and related liability issues, ${ }^{61}$ I agree with

${ }^{58}$ E.g., Howard v. Wal-Mart Stores, Inc., 160 F.3d 358, 359-60 (7th Cir. 1998); Smith v. Rapid Transit, Inc., 58 N.E.2d 754, 755 (Mass. 1945); Wright, Iowa L Rev 73 (1988) 1050 fn. 271. In the Howard case and again in United States v. Veysey, 334 F.3d 600, 605 (7th Cir. 2003), Judge Posner repeats the mathematical probabilists' "missing evidence" argument to try to explain the courts' rejection of such naked statistics. The flaws in that argument are discussed in Wright, Iowa L Rev 73 (1988) $1055 \mathrm{f}$.

${ }^{59}$ Goren (fn. 15) 73.

${ }^{60}$ Murray/Stürner (fn. 4) 312 f.; van Dam (fn. 2) 281 f.; van Gerven/Lever/Larouche (fn. 2) sec. 4.2.3, 428/17.

${ }^{61}$ Clermont/Sherwin, AJCL 50 (2002) 252-58, $273 \mathrm{f}$. 
Taruffo that it is those in the civil law jurisdictions that generally have a better understanding. ${ }^{62}$ Although, for the most part, their understanding has been intuitive rather than explained, they have understood more clearly, consistently and explicitly that neither ex ante causal probabilities nor naked statistics are relevant on the issue of what actually happened in a particular case, which must instead be proven through particularistic evidence that is specific to the particular situation, which alone is capable of supporting the necessary belief in what actually happened.

Jurisprudence in Italy has advanced further, particularly through the work of the late Federico Stella, who developed an analysis of proof based on complete instantiation of causal laws that is similar to but significantly different from the analysis in this Part. Stella distinguished a concept of "logical probability" from mere statistical probability. However, Stella's concept of logical probability was what I have called an ex ante causal probability (the frequency of occurrence of the consequent of a causal generalization given instantiation of the antecedent conditions). ${ }^{63}$ To establish actual causation in a particular instance, he insisted, the causal generalization being used must be an (almost) fully specified causal law, with a "logical probability" close to one, and there must be sufficient particularistic evidence specific to the particular case to enable the trier of fact to conclude that it was completely instantiated. ${ }^{64}$ This obviously is an extremely high standard of persuasion, as Stella as a criminal defense lawyer certainly intended it to be, in order to put a halt to Italian criminal convictions based merely on statistical probability and increased risk, which sometimes occurred even with statistical probabilities of less than 50 percent, and in order to have the standard of persuasion in criminal cases effectively raised to the level of "beyond a reasonable doubt."

Stella's goals seemed to be achieved in the landmark Franzese opinion of the Full Bench of the Criminal Division of the Supreme Court of Cassation in 2002. ${ }^{66}$ The court, employing Stella's "logical probability" terminology, held that findings of

${ }^{62}$ See Taruffo, AJCL 51 (2003) $662 \mathrm{ff}$.

${ }^{63}$ F. Stella, The Vitality of the Covering Law Model: Considerations on Wright and Mackie (available at http://works.bepress.com/richard_wright/34/) accessed on 16 July 2009, at 5 (translation by F. Stella of La vitalità del modello della sussunzione sotto leggi. A confronto il pensiero di Wright e Mackie, in: F. Stella, I Saperi del Giudice. La Causalità e Il Ragionevole Dubbio (2004) 1-70).

${ }^{64}$ Ibid.; F. Stella, Criminal omissions, causality, probability, counterfactuals: Medical-surgical activity (available at http://works.bepress.com/richard_wright/35/) accessed on 16 July 2009, at 14-18, 23 f. (translation by F. Stella of Causalità omissiva, probabilità, giudizi controfattuali: l'attività medico-chirurgica, in: F. Stella, Il Giudice Corpuscolariano. La Cultura delle Prove (2005) 201-43. Taruffo also refers to a concept of "logical probability" that is distinct from mere statistical probability, which however he attributes "mainly" to Jonathan Cohen. Taruffo, AJCL 51 (2003) 664 and fn. 20 (citing L.J. Cohen, The Probable and the Provable (1977)); see id. 659, 669 . The distinction that I make between causal prediction and causal explanation and the related distinction between ex ante causal probability and ex post causal probability is loosely based on Jonathan Cohen's distinction between "Pascalian" frequentist probability and "Baconian" inductive probability. See Wright, Iowa L Rev 73 (1988) $1044 \mathrm{ff}$. Cohen himself seems not to have fully grasped - or to have lost sight of - these distinctions. See Wright 1063 fn. 329.

65 See Stella (fn. 64) 1-2 (English translation).

${ }^{66}$ Cass. Crim. Sez. Un. 30328/02, Franzese [2002]. 
causation and criminal liability cannot be based merely on increased risk or even a high statistical probability of causation, but rather require resort to a rationally credible "covering law" and proof beyond a reasonable doubt, through particularistic evidence specific to the occasion, of the "real conditioning efficacy of [the conduct at issue] in the causal web." ${ }^{67}$ However, the precise nature of the "logical probability" standard established in Franzese apparently was not too clear and results in subsequent cases have been mixed. ${ }^{68}$ In the recent opinion of the Full Bench of the Civil Division of the Supreme Court of Cassation, which is quoted in Part B above, the same restrictions and requirements are stated and labeled "probabilistic certainty," with however proof by a "preponderance of the evidence" being substituted for proof "beyond a reasonable doubt" in civil actions. ${ }^{69}$

53 When Stella became aware of the analysis that is briefly described in this Part, which I previously have extensively elaborated and defended, ${ }^{70}$ he treated it as being essentially identical to his analysis by submerging the significant difference between his concept of logical probability and my concept of ex post causal probability, ${ }^{71}$ which however he described as "complet[ing] and defin[ing] my point of view on the application of the covering law model." 72 I greatly regret that his untimely death prevented us from embarking on a planned comparison and refinement of our respective views.

\section{E. Proof by Statistical Probability: Problems AND PARADOXES ${ }^{73}$}

\section{Indeterminate Defendants: The Alternative Causation Doctrine and Proportional Market Share Liability}

54 In both common law and civil law jurisdictions, an alternative causation doctrine is commonly applied in situations like the typical hunting accident situation, in which two (or more) defendants each fire in the direction of the plaintiff, who was hit by only one pellet, and it is impossible for the plaintiff to prove which defendant fired the pellet that injured him. In order to achieve a second-best just result in situations like this, when each defendant behaved tortiously and may have thereby caused the plaintiff's injury but it is impossible for the plaintiff to prove which defendant actually caused her injury, the courts shift the burden to each defendant to prove that she did not injure the plaintiff and hold each defendant who is unable to do so jointly and severally liable for the plaintiff's injury. ${ }^{74}$

${ }^{67}$ See Stella (fn. 64) 5-6 (English translation).

${ }^{68}$ Id. at 2-3, 23 ff.; V. Grembi, Trends and Duration of Medical Malpractice Cases: Some Evidence From the Italian Court of Cassation Decisions (1970-2005) (available at http://papers. ssrn.com/abstract=983039) accessed on 16 July 2009, at 11.

${ }^{69}$ See supra no. 25 .

${ }^{70}$ Wright, Iowa L Rev 73 (1988) $1044 \mathrm{ff}$.

${ }^{71}$ See Stella (fn. 64) 4 f., 12-16; Stella (fn. 63) 2 f., 7-10 (English translation).

72 Stella (fn. 63) 10 (English translation).

${ }^{73}$ Much of this Part is excerpted from Wright, Loy LA L Rev 41 (2008) 1295.

${ }^{74}$ Id. 1299 ff.; van Dam (fn. 2) 287 ff.; van Gerven/Lever/Larouche (fn. 2) sec. 4.4.3. 
However, if there are more than two defendants and the standard of persuasion is satisfied by a mere $50+$ percent statistical probability, the statistical probabilities by themselves ordinarily would enable each defendant to prove that she was not the cause of the injury, even though it is certain that one of the defendants caused the injury. For example, if there were three defendants, each equally likely to have been the cause of the plaintiff's injury, each defendant can "prove" that she was not the cause, since there is a 67 percent probability that she was not the cause, which leads to the paradoxical result that it can be "proven" that none of the defendants was the cause, even though we know that one of them must have been the cause.

Conversely, using what Mark Geistfeld calls "evidential grouping,"75 the statistical probability interpretation of the standard of persuasion can be employed iteratively to achieve the opposite paradoxical result: "proof" that all but one of the initial multiple defendants, each approximately equally likely (or unlikely) to have been the actual cause, was the actual cause. At each step in the iteration, a smaller group consisting of most of the defendants in the prior group can be carved out of the prior group, and the statistical probability interpretation of the standard of persuasion can be used to "prove" that this smaller group contains the defendant who actually caused the plaintiff's injury, until we are down to only two defendants, one of whom can be "proved" to have been the actual cause if there is even a "scintilla" of evidence, statistical or otherwise, to tip the probability one way or the other - for example, if the shotgun cartridge fired by one of the hunters contained one more pellet than the cartridge fired by the other hunter. ${ }^{76}$

The courts avoid each of these contrary paradoxical results by refusing to allow such naked statistics as proof or disproof of actual causation. ${ }^{77}$ As the reporters for the American Law Institute's Restatement (Third) of Torts state (despite their acceptance elsewhere of the statistical probability interpretation of the preponderance standard ${ }^{78}$ ),

Defendants would be able to satisfy their burden of production [under the alternative causation doctrine] when three or more defendants are subject to alternative liability [sic] in one of two ways: a defendant might show why it was not the cause of plaintiff's injury or it might show which one of the other defendants was the cause. ${ }^{79}$

To show why she was not the cause or which one of the other defendants was the cause, the defendant must produce evidence of the actual causal effect of another defendant's shot or the lack of causal effect of her own shot. To do this,

75 M.A. Geistfeld, The Doctrinal Unity of Alternative Liability and Market Share Liability, University of Pennsylvania Law Review (U Pa L Rev) 155 (2006) 447, 464 f., 466, 469.

76 See Wright, Loy LA L Rev 41 (2008) 1312 n. 64, 1330, 1332 f.

77 American Law Institute, Restatement (Third) of Torts: Liability for Physical Harm (Restatement Third) (Proposed Final Draft No. 1, 2005) § 28(b) and cmts. d(1) \& e, reporters' notes; American Law Institute, Restatement (Second) of Torts (1965) $\S \S 433 \mathrm{~B}(2)-(3)$.

78 American Law Institute, Restatement Third (Proposed Final Draft No. 1, 2005) $\S \S 26 \mathrm{cmt} .1$ \& illus. 5 , n. 28 cmt. a, reporters' note.

79 Id. $\S 28 \mathrm{cmt}$. j, reporters' note at 565 (emphasis added). 
she must provide concrete particularistic evidence specific to the particular occasion, rather than mere abstract ex ante causal probabilities or noncausal naked statistics, neither of which provide any information about what actually happened on the particular occasion.

59 When the preponderance standard is properly understood as requiring the formation of a minimal belief in the truth of a disputed fact, based on particularistic evidence specific to the particular occasion, the logical inconsistency that results from using the statistical probability interpretation of the preponderance standard in the alternative causation cases disappears. As Geistfeld states:

[T] he plaintiff has provided particularistic evidence showing that each defendant belongs to the group of [possible] tortfeasors that caused the harm, whereas each defendant [using the statistical probability argument] only relies upon "quantitative probability" or "the greater chance" that the other defendants caused the injury. That evidence, however, is not probative of what actually happened on this particular occasion .... To avoid liability, a defendant must instead provide [particularistic] evidence rebutting the plaintiff's particularized proof $\ldots{ }^{80}$

60 A further paradox would be produced by the statistical probability interpretation of the standard of persuasion when the same defendants are repetitively implicated as having possibly caused a particular type of injury. The Supreme Court of Oregon confronted such a situation in a case involving an injurious DPT vaccine that was supplied by one of two defendants, one of which had a 73 percent share of the market for the DPT vaccine. Literally applying the statistical probability interpretation of the preponderance standard would paradoxically result in its being "proven" that the defendant with the 73 percent market share, who was thus presumably only responsible for approximately 73 percent of the DPT-related vaccine injuries, caused 100 percent of those injuries. Although apparently accepting the statistical probability interpretation of the preponderance standard, the court, referring to articles discussing the "naked statistics" issue, did not allow either of the two defendants to be held liable, even under the alternative causation doctrine. ${ }^{81}$

61 The courts in the American DES cases may have faced a similar situation. It has been stated that one company, Eli Lilly, may well have supplied, directly or indirectly, more than half of the marketed DES ${ }^{82}$ It thus is worth noting how carefully the Supreme Court of California, in the leading American case, phrased its statements on proof of causation of the plaintiff's injury. The court observed that an inference of causation (based on statistical probability) would fail "if we measure the chance that any one of the defendants supplied the injury-causing drug by the number of possible tortfeasors" $" 83$ (rather than by

${ }^{80}$ Geistfeld, U Pa L Rev 155 (2006) 468.

${ }^{81}$ Senn v. Merrell-Dow Pharmaceuticals, Inc., 751 Pacific Reporters, Second Series (P.2d) 215, 216 n.1, 222 (Or. 1988)

82 See A.M. Levine, "Gilding the Lilly": A DES Update, Trial 20 (Dec. 1984) 18, $19 \mathrm{f}$.

${ }^{83}$ Sindell v. Abbott Labs., 607 P.2d 924, 931 (Cal. 1980) (emphasis added); see id. at $936 \mathrm{f}$. 
relative market share). Like the Oregon court, the California court also was unwilling to apply the alternative causation doctrine in this type of situation, since doing so would result in each defendant - even those with a minor share of the market - being held fully liable for all of the many DES-related injuries, even though the portion of the injuries that each defendant actually caused presumably approximated its share of the DES market. ${ }^{84}$

However, unlike the Oregon court, the California court devised a new second-best liability doctrine in an attempt to have each defendant be liable, approximately, for the share of the total DES-related damages that it presumably actually caused, by holding each defendant proportionately liable in each case for a share of the damages in that case equal to its share of the DES market. ${ }^{85}$ Some courts, in both common law and civil law jurisdictions, have imposed more extensive liability in the DES cases, but they have done so as a matter of normative policy while recognizing that it is impossible to prove who actually caused the plaintiff's injury in each case. ${ }^{86}$

\section{Toxic Exposures: The Doubling of the Risk Doctrine}

Although phrases such as "more likely than not" or "balance of probabilities" have long been part of the legal language regarding the standard of persuasion in tort law and other areas of civil law, it is only in fairly recent years that they have come to be understood as mere statistical probability statements. A major locus of this shift in understanding is the toxic tort cases, in which proof often depends on, and often consists solely of, statistical epidemiological evidence. As I discussed in Part D above, ${ }^{87}$ such evidence is very useful, although neither necessary nor sufficient, in establishing that a toxic substance is capable of causing a particular kind of injury - the causal capacity or "general causation" issue - and, if such causal capacity has been sufficiently established, in predicting possible results ex ante or comparing possible causes ex post for purposes of remedial treatment. However, such evidence has also incorrectly come to be viewed by many courts as being sufficient to prove the actual occurrence of the relevant causal process on a particular occasion - "specific causation" - if exposures to the substance more than double, in the aggregate, the frequency of occurrence of that kind of injury, so that it can be said, whenever that kind of injury occurs following exposure to the substance, that the injury was (statistically) "more likely than not" caused by the exposure to the substance. ${ }^{88}$

As in the indeterminate defendant cases, the statistical probability interpretation of the burden of persuasion produces odd results in the toxic exposure

84 Id. 1325.

85 Id. $1325 \mathrm{f}$.

86 B. v. Bayer Nederland BV, Hoge Raad 9 October 1992, [1994] Nederlandse Jurisprudentie (NJ) 535 (C.J.H.B.); Collins v. Eli Lilly Co., 34 North Western Reporter (N.W.2d) 37 (Wis. 1984); Martin v. Abbott Labs., 689 P.2d 368 (Wash. 1984).

87 See supra no. 39.

${ }^{88}$ E.g., Daubert v. Merrell Dow Pharm., Inc., 43 F.3d 1311, 1313-14, 1318-22 (9th Cir. 1995); Marder v. G.D. Searle \& Co., 630 F. Supp. 1087, 1092 (D. Md. 1986), aff'd, 814 F.2d 655 (4th Cir. 1987); American Law Institute (fn. 78) § 28 cmt. c(4). 
cases. When exposure to a substance more than doubles the risk, the "doubling+" doctrine will result in defendants being held liable for every instance of the injury that occurs following exposure to the substance, even if there is no evidence that the substance actually caused the injury on any particular occasion, and even though exposure to the substance could only have caused a portion of the injuries. For example, if exposure to the substance barely doubles the frequency of occurrence of the injury, so that just over half of the injuries that occur following exposure to the substance are caused by that exposure, defendants nevertheless will be held liable in every case, for all of the injuries. Conversely, when, as is usually the case, exposure to the substance does not more than double the frequency of occurrence of the injury, no defendant will be liable for any of the injuries that occur following exposure to the substance, no matter how many may actually have been caused by such exposure, even though as many as half of the injuries may be due to exposure to the substance. It is remarkable that such a miniscule difference in statistical probability should be thought to result in such a dramatic difference in the supposed proof of causation and resultant liability. ${ }^{89}$

65 Some American courts recognize this. As one such court stated, "numerous jurisdictions have rejected medical experts' conclusions based upon a 'probability,' a 'likelihood,' and an opinion that something is 'more likely than not' as insufficient medical proof," and instead have required that the expert express a "reasonable medical certainty" about the fact at issue. ${ }^{90}$ Unfortunately, "reasonable certainty" standards are not employed and have no meaning in the medical and scientific communities, so the plaintiff's attorney can and often does fill the semantic void, and the plaintiff's expert then employs the required terminology. ${ }^{91}$

66 Doctors and scientists understand that a mere statistical probability, while useful for diagnosis and prediction, is insufficient to establish what actually happened in a particular case. Thus, if an expert's opinion regarding actual causation, whether couched in terms of "reasonable certainty", "more likely than not", or "preponderance of the evidence", is based only on a statistical probability (as is usually true in the toxic exposure cases), a good defense attorney will ask the expert, "Can you say whether the plaintiff's exposure to the [relevant substance] actually caused the [relevant specific harm] in this case?" The expert - if honest - will reply, "No", and be chagrined for having been made to appear to have contradicted her earlier testimony.

${ }^{89}$ Clermont and Sherwin dismiss this objection as an "appealing but unsound lay intuition" that conflicts with the supposed basic goal of minimizing erroneous judgments. Clermont/Sherwin, AJCL 50 (2002) 252; see id. 258.

90 Sterling v. Velsicol Chem. Corp., 855 F.2d 1188, 1200-01 (6th Cir. 1988); see American Law Institute (fn. 78) § $28 \mathrm{cmt}$. a.

${ }^{91}$ American Law Institute (fn. 78) $§ 28 \mathrm{cmt}$. a and cmt. a reporters' note. 


\section{Professional Malpractice: Lost Chances}

An identical situation exists in many common law and some civil law jurisdictions in the medical malpractice context. In these jurisdictions, the courts, applying the statistical probability interpretation of the standard of persuasion, erroneously assume that, if the doctor's negligence in diagnosing or treating an ill patient deprived the patient of a 50+ percent statistical probability of avoiding the injury that subsequently occurred (generally, death), then the doctor's negligent causation of the injury is easily - indeed, certainly - proven; however, if the patient was deprived of a less than a 50+ percent statistical probability of avoiding the injury, the defendant's negligent causation of the injury is not deemed to be proven (indeed, theoretically it is disproven) and the defendant is not liable. ${ }^{92}$ The same result is reached in German law, through a rule shifting the burden of proof of lack of causation to the defendant doctor in cases of gross medical negligence that deprived the plaintiff of a 50+ percent probability of avoiding the injury. ${ }^{93}$ Under either approach, proof of actual causation (or its lack) and all-or-nothing liability arbitrarily turns on a trivial difference in statistical probability.

Some courts, in both common law and civil law jurisdictions, while supposedly adhering to the usual requirement that the plaintiff prove the defendant's tortious causation of the plaintiff's injury, but influenced by the statistical probability interpretation of the standard of persuasion and perhaps by the arbitrary distinction under that standard between trivial differences in statistical probability, have been willing to treat any significant increase in risk (or its converse, loss of any significant chance of avoiding the injury) as proof of, or equivalent to, actual causation of the injury and thus as supporting holding the defendant fully liable for the injury. ${ }^{94}$

Other courts, including many American courts, while treating the defendant's depriving the plaintiff of a 50+ percent chance of avoiding the injury as proof of actual causation and consequent full liability, acknowledge that causation is not proven when the plaintiff had less than a 50+ percent chance of survival, but (supposedly) hold the defendant liable for having caused a newly recognized legal injury, the plaintiff's "lost chance" of avoiding the tangible injury that actually occurred, with liability being imposed for a portion of the tangible injury equal to the lost chance. ${ }^{95}$ The same theory is followed in France whether the probability is greater or less than 50 percent. ${ }^{96}$ This approach (except in France) continues to base significant, albeit reduced, substantive differences in liability on mere trivial differences in statistical probability. Moreover, even

92 See, e.g., Kramer v. Lewisville Mem'l. Hosp., 858 S.W.2d 397, 399-400 (Tex. 1993); American Law Institute (fn. 78) $\S 26 \mathrm{cmt}$. n (assuming proof of causation, and thus full liability, if "the probability of a better outcome was in excess of 50 percent"); van Dam (fn. 2) 295 ff.

93 van Dam (fn. 2) 296.

${ }^{94}$ Stella (fn. 64) 1 f. (English translation); Wright, Iowa L Rev 73 (1988) 1067 ff.; supra fn. 25 (Italian cases).

95 Wright, Iowa L Rev 73 (1988) 1067-72.

${ }^{96} \operatorname{van} \operatorname{Dam}$ (fn. 2) $293 \mathrm{f}$. The lost chance theory is applied widely in France. Id. In many other jurisdictions - especially in the United States - it is applied only in medical malpractice cases. 
in France, it erroneously equates aggregate statistical probabilities of avoiding the tangible injury with the particular plaintiff's probability of avoiding that injury in the particular situation, which will vary depending on his particular genetic makeup and other relevant conditions, and, while claiming to impose liability for having caused the (particular) lost chance, it actually imposes liability not for the lost chance - the mere imposition of unrealized risk - but rather for the plaintiff's actual tangible injury, in the acknowledged absence of proof of causation of that tangible injury. No liability is imposed for the lost chance in the absence of the physical injury, and the liability that is imposed when there is a physical injury (which may or may not have been affected or caused by the lost chance) is not for the (statistical) value of the lost chance, but rather for the damages resulting from the physical injury, reduced in proportion to the statistical lost chance.

70 Oddly, in the United Kingdom, the lost chance doctrine is applied with respect to financial losses in contractual relationships, including the attorney-client relationship, but not in medical malpractice cases. ${ }^{97}$ The English position is even odder when one considers that the usual justification for employing the lost chance doctrine or some other second-best liability rule is the inherent impossibility of proving causation. ${ }^{98}$ In legal malpractice cases, the trial that did not occur or that was botched can be re-litigated - "a trial within a trial," as occurs in the United States - to determine whether the plaintiff would have won or lost; there is no need for a lost chance doctrine. The same is not true in medical malpractice cases.

71 The British House of Lords' decision in the Hotson medical malpractice case ${ }^{99}$ is an especially dramatic example of the perverse results that often are caused by the statistical probability interpretation of the standard of persuasion. The plaintiff fell from a tree and ruptured some of the blood vessels in his left femoral epiphysis. The defendant's negligent delay in diagnosing and treating his injury caused a swelling of the epiphysis that compressed the remaining intact blood vessels and thus shut off the supply of blood from those blood vessels. As a result of the combined loss of blood from the initial fall and ruptures and the subsequent compression of the remaining blood vessels, the epiphysis became distorted and deformed, resulting in permanent injury to the boy's left hip and leg. However, the trial court determined that there was a 75 percent chance that the permanent injury would have happened anyway even if the defendant had not been negligent, due to the loss of blood from the ruptured blood vessels. Focusing on this finding, the House of Lords held that the defendant was not liable due to lack of causation, which as a past fact is determined by the "balance of probabilities" - the British version of the preponderance of the evidence standard of persuasion. ${ }^{100}$ Adding insult to injury, the court further held that there could be no recovery for any lost chance: "In

97 Id. $294 \mathrm{f}$.

98 See Wright, Loy LA L Rev 41 (2008) 1295 ff.

99 Hotson v. East Berkshire Area Health Authority, [1987] 1 Appeal Cases (A.C.) 750.

100 See Wright, Loy LA L Rev 41 (2008) 1322 f. 
determining what did happen in the past a court decides on the balance of probabilities. Anything that is more probable than not it treats as certain."101 After using a statistical probability argument to find a lack of causation, the court makes the plaintiff's 25 percent chance of avoiding the injury disappear through judicial ipse dixit!

However, that is not the worst part of the court's decision. The worst part is the court's denial of actual causation, as a result of combining the statistical probability interpretation of the standard of persuasion with the but-for test of causation. Although the plaintiff most likely would have suffered the permanent injury anyway, the defendant's negligence, by causing the loss of the blood supply from the intact blood vessels, contributed to the aggregate loss of blood that caused the permanent injury (and likely was a but-for cause of this happening earlier than it otherwise would have), just as stabbing a person who more likely than not already has been stabbed sufficient times to bleed to death, but who still has a significant amount of blood left and several hours to live, contributes to that person's bleeding to death (and likely is a but-for cause of the death happening earlier than it otherwise would have). ${ }^{102}$

\section{Res Ipsa Loquitur and "Prima Facie" Presumptions}

The last doctrine to be discussed is the res ipsa loquitur doctrine, which seems to exist in every jurisdiction even though it sometimes is known by a different name (e.g., as the "prima facie" evidence doctrine in Germany). ${ }^{103}$

The res ipsa loquitur doctrine, as usually stated, allows an inference of negligent causation of the plaintiff's injury by the defendant if (a) in the type of situation that existed the injury ordinarily does not occur unless there is negligence and (b) other possible responsible causes are sufficiently eliminated by the evidence. ${ }^{104}$ Although condition (b) may put some limitations on the scope of the doctrine, depending on how it is interpreted, ${ }^{105}$ it constitutes a departure from the ordinary substantive liability rules and proof rules of a magnitude that is not commonly appreciated. The doctrine allows an inference of negligent conduct by the defendant, and a further inference that the inferred negligence caused the plaintiff's injury, based on a mere ex ante statistical frequency. If, in the aggregate, most $(50+$ percent $)$ occurrences of this type of event are caused by negligence, then negligent causation by the defendant can be inferred without any specific evidence of negligence or causation by the defendant or anyone else on the particular occasion.

101 Hotson (fn. 99) 785 (Lord MacKay) (quoting Mallett v. McMonagle, [1970] A.C. 166, 176 (Lord Diplock)); accord, Hotson, 1 [1987] A.C. at 792 (Lord Ackner).

102 See R. Wright, Acts and Omissions as Positive and Negative Causes, in J.W. Neyers/E. Chamberlain/S.G.A. Pitel (eds.), Emerging Issues in Tort Law (2007) 287, 295-97, 299.

103 Murray/Stürner (fn. 4) 312 f.; van Dam (fn. 2) 1107; van Gerven/Lever/Larouche (fn. 2) sec. 4.2 .3 at $428 / 15 \mathrm{ff}$.

104 E.g., American Law Institute, Restatement (Second) of Torts (1965) § 328D(1).

105 See Wright, Loy LA L Rev 41 (2008) 1338 ff. 
75 Thus, contrary to what is commonly stated, ${ }^{106}$ it is not true that res ipsa loquitur is merely a fancy Latin name, employed in the particular context of proving the defendant's causal negligence, for the ordinary use of circumstantial evidence to make a straightforward factual inference. Circumstantial evidence is concrete evidence specific to the particular occasion about the network of instantiated causal relationships leading to and flowing from the particular factual issue being litigated. For example, a person's running away from the scene of a murder immediately after it happened with blood on her that matches the victim's blood and holding a knife, the blade of which matches the victim's stab wound, is strong circumstantial evidence that she stabbed the victim. The inference of negligence allowed by the res ipsa loquitur doctrine as stated by many courts, interpreted literally, does not require any such case-specific evidence of what actually happened on the particular occasion, but rather only abstract statistical data (or assumptions) on what usually (50+ percent of the time) has happened in such situations. The difference in the validity of the inference depending on whether or not the word "ordinarily" is included parallels the distinction between the admissibility of habit evidence (allowed) and character evidence (generally not allowed) to prove what a person did on a particular occasion. ${ }^{107}$

76 The common failure to appreciate the extraordinary nature of the res ipsa loquitur doctrine is probably attributable to an assumption that the word "ordinarily" in the first condition is simply an incorporation of the preponderance of the evidence standard, interpreted as merely requiring a $50+$ percent statistical probability. Once again, however, taking this interpretation seriously immediately raises a logical contradiction. Why, if the first condition is satisfied, is the inference that someone was negligent only a permissive one, rather than being required? Why, in the absence of any contrary evidence by the defendant, allow the trier of fact not to draw the inference once the conditions for drawing the inference have been established, especially since this permits inconsistent verdicts by different juries in similar situations, which is a denial of formal justice?

77 The reason, I suspect, is a discomfort with the broad formulation of the doctrine, especially when there is a conscious realization that it permits an inference of negligence by the defendant based merely on aggregate statistical frequency. Allowing the trier of fact not to draw the inference may be an implicit concession that she should be able to draw the inference or not depending on whether she actually believes the defendant was causally negligent in the particular situation. But if the existence of such an actual belief is the concern, the broad formulation should be abandoned in favor of the narrow one (with

106 E.g., W.L. Prosser/W.P. Keeton/D.B. Dobbs/R.E. Keeton/D.G. Owen, Prosser and Keeton on Torts (5th ed. 1984) § 39, at 243 f. \& fn. 20; American Law Institute (fn. 104) § 328D cmt. a. But see D.B. Dobbs, The Law of Torts (2000) § 154, at 372 (noting, correctly, that res ipsa loquitur cases differ "overwhelmingly" from ordinary circumstantial evidence cases by allowing an inference of negligence [and causation] without any particularistic evidence of negligence [or causation] on the particular occasion).

107 E.g., K.S. Broun et al. (eds.), McCormick on Evidence (6th ed. 2006) vol. 1 §§ 186, 188, 195. 
the word "ordinarily" omitted), or at least the trier of fact should be instructed that an inference of negligent causation should be drawn only if evidence specific to the particular case combines with the "ordinarily would not happen" statistical frequency to raise a minimal belief that the defendant actually was negligent in the particular situation and that such negligence contributed to the plaintiff's injury. On the other hand, if the broad formulation is meant to provide a second-best (or third-best) resolution of the factual uncertainty regarding negligent causation, it seems that decision should be consistently implemented through a rebuttable presumption. 